\title{
Association between Allelic Variations of -174G/C Polymorphism of Interleukin- 6 Gene and Chronic Kidney Disease-Mineral and Bone Disorder in Iraqi Patients
}

\author{
Mohanad Yasir Al-Radeef
}

Clinical Pharmacy Department, College of Pharmacy, University of Tikrit, Tikrit, Iraq.

E-mail: mohanadyasir@tu.edu.iq

ORCID ID: https://orcid.org/0000-0001-6363-7277

Received 4/5/2019, Accepted 6/2/2020, Published 1/12/2020

This work is licensed under a Creative Commons Attribution 4.0 International License.

\begin{abstract}
:
This study was designed to examine association between -174G/C polymorphism of interleukin-6 gene and phosphate, calcium, vitamin $\mathrm{D}_{3}$, and parathyroid hormone levels in Iraqi patient with chronic kidney disease on maintenance hemodialysis. Seventy patients with chronic renal disease (patients group) and 20 healthy subjects (control group) were enrolled and genotyped for interleukin-6 polymorphism by conventional polymerase chain reaction-restriction fragment length polymorphism. There were no significant differences in phosphate levels observed in both patient and control groups with different interleukin-6 genotypes. Control had non-significant differences in calcium levels, while patients with GG and GC genotypes showed significant elevation with time. Conversely, control and patients with GG and $\mathrm{CC}$ genotypes had significant elevation in vitamin $\mathrm{D}_{3}$ levels with time. Regarding parathyroid hormone, control had non-significant differences, while patients with GG and CC genotypes showed significant elevation with time. A significant association was found between CKD patients with GG genotype and serum levels of calcium, vitamin $\mathrm{D}_{3}$ and parathyroid hormone.
\end{abstract}

Key words: CKD-MBD, Genetic polymorphism, Hemodialysis, Interleukin-6.

\section{Introduction:}

The effect of genetic variation in renal failure development is becoming clearer and highlights the necessity to demonstrate the genetic basis for renal diseases as well as their complications (1). The major complications related to chronic kidney disease (CKD) include cardiovascular disease, neuropathy, infectious complications, anemia, and abnormalities related to mineral bone metabolism (2). Chronic kidney disease-mineral and bone disorder (CKD-MBD) is a systemic disorder of bone and mineral metabolism because of CKD usually explained by either one or a combination of the following:

- Abnormalities of biochemical parameters of phosphorus, calcium, parathyroid hormone $(\mathrm{PTH})$, or vitamin D metabolism.

- Abnormalities of bone mineralization, volume, strength, turnover, or linear growth.

- Calcification of vascular tissue or other softtissue $(3,4,5)$.

Bone and mineral metabolism in end stage renal disease (ESRD) patients appears to be under the influence of genetic control, with various genes playing a critical role. However, gene polymorphism association studies to date have revealed conflicting results with low reproducibility (6).

Interleukin-6 (IL-6) is a cytokine involved not only in inflammation and infection responses but also in the regulation of metabolic, regenerative, and neural processes (7). It has an important role in the bone tissues by acting on the cells of bones (osteoblasts and osteoclasts) (8). Expression of IL-6 and IL-6 receptor messenger RNA (mRNA) has been demonstrated in osteoclasts and bone marrow cells, with the most intense expression in the areas of the highest bone resorption (6). Bone resorbing effects of $\beta_{2}$-microglobulin have also been partly attributed to induction of IL- 6 production by osteoblasts (6).

In addition, clinical and experimental studies suggest that IL-6 contributes to renal injury in glomerulonephritis and other forms of renal disease (9). The causes of elevated plasma IL-6 levels in ESRD patients may be related to a multitude of 
different factors. Even before the initiation of dialysis therapy, patients with decreased renal function demonstrate signs of inflammation. Ultimately, the role of IL- 6 in these conditions may relate to IL-6 involvement in fibrosis and tissue damage (10).

Circulating levels of IL-6 are genetically regulated. The $-174 \mathrm{G} / \mathrm{C}$ single-nucleotide polymorphism is a functional variant located in the promoter region of the IL- 6 gene that regulates the rate of IL-6 gene transcription and therefore represents a reliable research tool for testing the nature (causal versus non-causal) of the link between IL- 6 and cardiovascular outcomes in CKD patients (11).

To date, little researches have been devoted to studying the association between polymorphisms of IL-6 gene (at promotor region $-174 \mathrm{G} / \mathrm{C}$ ) and risk of CKD-MBD in worldwide populations. Gohda et al. (12) investigated the association of $(\mathrm{CA})_{\mathrm{n}}$ repeat polymorphism of the IL-6 gene with bone mineral density in 165 hemodialysis patients. Patients with the AA genotype had the lowest bone mineral density score and those with the OO genotype the lowest serum PTH levels, suggesting that this genetic locus may play an important role in the regulation of bone mineral density in hemodialysis patients. Recent epidemiologic studies have demonstrated that many patients undergoing maintenance hemodialysis are out of the target ranges of serum phosphorus, calcium, vitamin D, and intact PTH (13). Therefore, necessity has been felt for determining the presence of such disorders in Iraqi CKD patients on hemodialysis and whether genetic polymorphism of IL-6 gene has a significant result on these parameters in such patients. Hence, this present study was designed to observe and examine the association between allelic variations of $-174 \mathrm{G} / \mathrm{C}$ polymorphism of IL-6 gene and the phosphorus, calcium, vitamin D, and PTH levels in the serum of Iraqi CKD patient undergoing maintenance hemodialysis.

\section{Materials and Methods:}

Ninety participants of both genders attending Iraqi center of kidney dialysis, Baghdad, Iraq were selected from November 2015 until June 2016 to enroll in this current study after the approval of the committee of local ethics in college of medicine, University of Baghdad, Iraq with informed verbal consent from each participant. These participants were grouped into two groups:

Patient Group: Include $70 \mathrm{CKD}$ patients (40 males and 30 females) on maintenance hemodialysis for $\geq$ six months.
Control Group: Includes 20 healthy subjects (10 males and 10 females) without medical illnesses such as renal disease, prior or current history of renal stone, diabetes mellitus, or hypertension.

Any participant with hypertensive crises, renal carcinoma, psychiatric disorders, genetic disorders, inadequate data, age $<18$ years, and those with recent signs and symptoms of bleeding that required a blood transfusion were excluded from this study.

\section{Laboratory Measurements}

Three samples of whole blood were obtained from each CKD patient at the beginning of this study (baseline sample), after 3 months, and then after 6 months of baseline sample while a single sample of blood was collected from each control group's subject. Three millimeters of blood were drawn from the participants. Two millimeters were allowed to stand at room temperature and then centrifuged to get serum that was stored at $\left(-40^{\circ} \mathrm{C}\right)$ until time for the assay. The remaining one milliliter of the blood sample was transferred to a clean tube containing EDTA and stored at $\left(-40^{\circ} \mathrm{C}\right)$ until time for genomic DNA analysis.

Serum calcium was determined by photometric method using commercially available kit (Biomérieux, France) that enables colorimetric determination of total calcium, without deproteinization. The calcium ion reacts with the methylthymol blue indicator (MTB) in an alkaline medium, and the color intensity of the Ca-MTB complex is proportional to the quantity of calcium present in the sample. The measured serum calcium was corrected for serum albumin concentration and calculated as follows: if serum albumin was $\geq 4.0$ $\mathrm{g} / \mathrm{dl}$, then corrected calcium is equal to serum calcium; if serum albumin was $<4.0 \mathrm{~g} / \mathrm{dl}$, then albumin-corrected calcium $=$ measured $\mathrm{Ca}[\mathrm{mg} / \mathrm{dl}]$ $+0.8 \times(4 \mathrm{~g} / \mathrm{dl}-$ measured albumin $[\mathrm{g} / \mathrm{dl}])$.

Serum phosphorus was determined by photometric method using commercially available kit (Linear chemical, Spain) in that inorganic phosphate reacts with molybdic acid forming a phosphomolybdic complex. Its subsequent reduction in alkaline medium originates a blue molybdenum color which intensity is proportional to the amount of phosphorus present in the sample. Calcium and phosphorus measurements were performed using the Spectrophotometer-CE 1011 (Cecil, England).

Serum 1,25-dihydroxy vitamin $\mathrm{D}_{3}$ was determined by using the immunoassay kit (Shanghai Yehua Biological Technology, China) that is an enzyme-linked immune sorbent assay (ELISA) based on biotin double antibody sandwich technology to assay human 1,25-dihydroxyvitamin $\mathrm{D}_{3}$. Add 1,25-dihydroxyvitamin $\mathrm{D}_{3}\left(\mathrm{DVD}, \mathrm{DHVD}_{3}\right)$ 
to wells that are pre-coated with 1,25dihydroxyvitamin $\mathrm{D}_{3}\left(\mathrm{DVD}, \mathrm{DHVD}_{3}\right)$ monoclonal antibody. After incubation, add anti-DVD, $\mathrm{DHVD}_{3}$ antibodies labeled with biotin to unite with streptavidin-horseradish peroxidase, which forms the immune complex. Remove unbound enzymes after incubation and washing, and then add substrates. The solution will turn blue and change to yellow with the effect of acid. The shades of the solution and the concentration of human 1,25dihydroxyvitamin $\mathrm{D}_{3}\left(\mathrm{DVD}, \mathrm{DHVD}_{3}\right)$ are positively correlated.

Serum PTH was determined by using the DEMEDITEC intact PTH immunoassay (DEMEDITEC Diagnostics GmbH, Germany) that is a two-site ELISA for the measurement of the biologically intact 84 amino acid chain of PTH. In this assay, calibrators, controls, or patient samples are simultaneously incubated with the enzymelabeled antibody and a biotin coupled antibody in a streptavidin-coated microplate well. At the end of the assay incubation, the microwell is washed to remove unbound components and the enzyme bound to the solid phase is incubated with the substrate, tetramethylbenzidine. An acidic stopping solution is then added to stop the reaction and converts the color to yellow. The intensity of the yellow color is directly proportional to the concentration of intact PTH in the sample. The measurements of serum 1,25-dihydroxy vitamin $\mathrm{D}_{3}$ and PTH were performed by using Biotek/ELx 800 ELISA reader (Biotek, USA).

Genotyping of $-174 G / C$ Polymorphism of IL-6 gene:

Genomic DNA was extracted from whole blood samples (baseline samples) using genomic DNA extraction kit (Reliaprep ${ }^{\mathrm{TM}}$ Blood gDNA Miniprep system, Promega, USA) and the quality of DNA was analyzed by agarose gel electrophoresis (AgaroPower $^{\mathrm{TM}}$, Bioneer, Republic of Korea). Genotyping of IL-6 gene $(-174 \mathrm{G} / \mathrm{C})$ was made with the aid of conventional polymerase chain reaction-restriction fragment length polymorphism (PCR-RFLP) (MyGenie ${ }^{\mathrm{TM}} 96$ Thermal Block, Bioneer, Republic of Korea) according to the method of Al-Radeef et al. (14). The following primers were used for PCR amplification:

Forward: 5' TGA CTT CAG CTT TAC TCT TGT 3'

Reverse: 5' CTG ATT GGA AAC CTT ATT AAG 3'

The condition for PCR reaction has been provided in Table 1. PCR products were then digested with 1 unit of NlaIII restriction enzyme. After incubation at $37^{\circ} \mathrm{C}$ for two hours, the enzyme cut the 198 base pair (bp) PCR's product into four fragments 168, 119, 49 and $30 \mathrm{bp}$ in length. The resulting products were tested by $3 \%$ agarose gel electrophoresis at 150 volts for $60 \mathrm{~min}$ and visualized at room temperature under UV light after ethidium bromide $(0.5 \mu \mathrm{g} / \mathrm{ml})$ staining. Samples with fragments size of 168, 49 and $30 \mathrm{bp}$ indicated the presence of homozygous GG genotype. Samples with fragments size of $168,119,49$ and $30 \mathrm{bp}$ indicated the presence of heterozygous GC genotype, while samples with fragments size of 119 and $49 \mathrm{bp}$ indicated the presence of a homozygous CC genotype.

Table 1. PCR conditions for the detection of IL-6 gene polymorphism.

\begin{tabular}{|c|c|c|c|c|}
\hline Stage & Steps & Temperature & Time & $\begin{array}{l}\text { No. of } \\
\text { cycles }\end{array}$ \\
\hline 1. & $\begin{array}{c}\text { Initial } \\
\text { denaturation }\end{array}$ & $95^{\circ} \mathrm{C}$ & $\begin{array}{c}3 \\
\text { minutes }\end{array}$ & 1 \\
\hline & Denaturation & $95^{\circ} \mathrm{C}$ & $\begin{array}{c}30 \\
\text { seconds }\end{array}$ & \\
\hline 2. & Annealing & $53^{\circ} \mathrm{C}$ & $\begin{array}{c}30 \\
\text { seconds }\end{array}$ & 35 \\
\hline & Extension & $72^{\circ} \mathrm{C}$ & $\begin{array}{c}30 \\
\text { seconds }\end{array}$ & \\
\hline 3. & $\begin{array}{c}\text { Final } \\
\text { extension }\end{array}$ & $72^{\circ} \mathrm{C}$ & $\begin{array}{c}5 \\
\text { minutes }\end{array}$ & 1 \\
\hline
\end{tabular}

Statistical analysis

Statistical calculations were done using the Minitab version 17 and SPSS program version 20.0 software, with a $\mathrm{p}$ value of $<0.05$ was considered significant statistically. The adherence of continuous variables to normal distribution was tested with Anderson-Darling test. Variables with normal distribution were described by using their mean with their standard deviation (SD), while variables that were non-normally distributed were presented by using their median with their interquartile range (IQR). The Chi-square test was used for comparisons of discrete variables between each study group.

\section{Results}

The RFLP detection system is outlined in Fig. 1. The distribution of IL- 6 genotypes between the study groups is similar ( $>0.05)$ as shown in Table 2. 


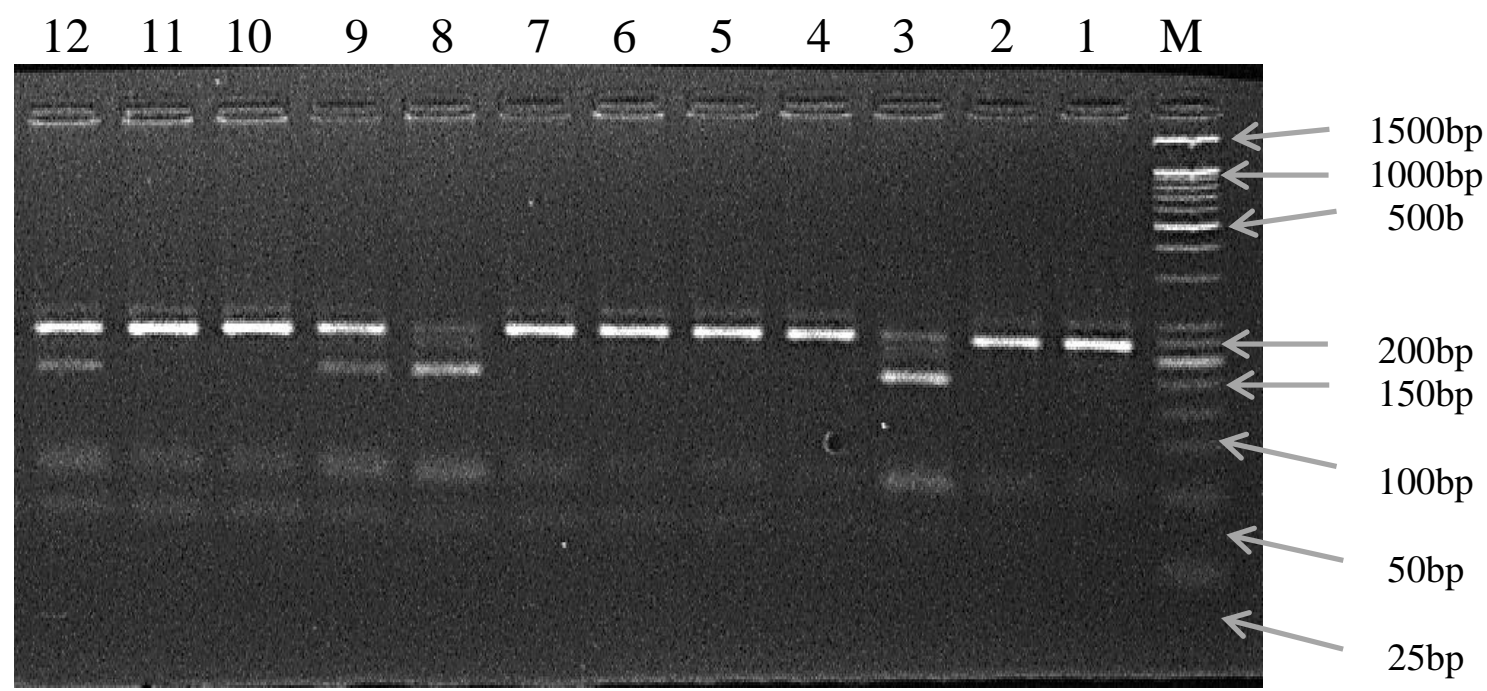

Figure 1. A 3\% agarose gel electrophoresis. Lane M: DNA Ladder. Lane 3 and 8: indicates CC homozygote genotype (bands at 119 bp and 49 bp). Lane 1,2,4,5,6,7,10 and 11: indicates GG homozygote genotype (bands at $168 \mathrm{bp}, 49 \mathrm{bp}$ and $30 \mathrm{bp}$ ). Lane 9 and 12: indicates GC heterozygote genotype (bands at $168 \mathrm{bp}, 119 \mathrm{bp}, 49 \mathrm{bp}$ and $30 \mathrm{bp}$ ).

Table 2. Distribution of IL-6 gene polymorphism in the study groups.

\begin{tabular}{ccccc}
\hline Genotypes & & Control & Patients & P value \\
\hline GG & (n) & 15 & 48 & 0.467 \\
& \% & 75.0 & 68.6 & \\
GC & $(\mathbf{n})$ & 5 & 17 & \\
& \% & 25.0 & 24.3 & \\
CC & $(\mathbf{n})$ & 0 & 5 & \\
& \% & 0.0 & 7.1 &
\end{tabular}

Chi-square test

Serum phosphate was significantly elevated $(p<0.05)$ in patients when compared to control at baseline, while in patients group there was insignificant change $(p>0.05)$ over time from baseline toward 6 months as shown in Table 3. As illustrated in Table 4, the control and patients groups exhibited insignificant differences $(p>0.05)$ in serum phosphate levels at all time periods among different IL-6 genotypes. According to individual IL-6 genotypes, patients with different IL-6 genotypes displayed a negligible alteration $(p>0.05)$ in the serum phosphate levels with time.

Table 3. Serum phosphate levels (mg/dl) in study groups throughout the study.

\begin{tabular}{|c|c|c|c|c|c|}
\hline \multirow[t]{2}{*}{ Variables } & \multicolumn{2}{|c|}{ Patients } & \multicolumn{2}{|c|}{ Control } & \multirow[t]{2}{*}{ P value $^{a}$} \\
\hline & Mean & $S D$ & Mean & $S D$ & \\
\hline Baseline & 5.82 & 1.56 & 3.56 & 0.73 & \\
\hline $3 \mathrm{~m}$ & 5.68 & & $--*$ & -- & -- \\
\hline $6 \mathrm{~m}$ & 5.99 & 0.93 & $--*$ & -- & -- \\
\hline$P$ value ${ }^{b}$ & \multicolumn{2}{|c|}{0.328} & -- & -- & -- \\
\hline \multicolumn{6}{|c|}{$\begin{array}{l}{ }^{a}: \text { Independent } 2 \text { sample t-test } \\
b: \text { One-way ANOVA (parametric test) } \\
*: \text { Values were not measured because these subjects presented } \\
\text { without any disease or condition that may have a significant } \\
\text { effect on serum phosphate levels }\end{array}$} \\
\hline
\end{tabular}

Table 4. Serum phosphate levels $(\mathrm{mg} / \mathrm{dl})$ divided by IL-6 gene polymorphism. Data expressed as mean \pm SD.

\begin{tabular}{ccccc}
\hline Variables & GG & GC & CC & $\begin{array}{c}\text { P } \\
\text { value }\end{array}$ \\
\hline Control & $3.65 \pm$ & $3.32 \pm$ & -- & $0.395^{\boldsymbol{a}}$ \\
baseline & 0.71 & 0.82 & & \\
Patient & $5.76 \pm$ & $5.71 \pm$ & $6.79 \pm$ & $0.105^{\boldsymbol{b}}$ \\
baseline & 1.69 & 1.30 & 1.32 & \\
Patient 3 & $5.90 \pm$ & $5.34 \pm$ & $4.78 \pm$ & $0.064^{\boldsymbol{b}}$ \\
months & 1.32 & 0.90 & 1.13 & \\
Patient 6 & $6.14 \pm$ & $5.56 \pm$ & $6.08 \pm$ & $0.106^{\boldsymbol{b}}$ \\
months & 0.87 & 1.07 & 0.72 & \\
P value & $0.094^{c}$ & $0.589^{c}$ & $0.165^{c}$ & \\
${ }^{\boldsymbol{a}}:$ Independent 2 sample t-test & & & \\
${ }^{\boldsymbol{}}:$ : One-way ANOVA & & & \\
${ }^{c}:$ Trend ANOVA (among patients group only) & \\
\hline
\end{tabular}

As illustrated in Table 5, the mean of corrected serum calcium levels was significantly $(p<0.05)$ reduced in patients when compared to control. This value was significantly $(\mathrm{p}<0.05)$ increased in patients group throughout the study. As illustrated in Table 6, the control group had insignificant $(p>0.05)$ variations in corrected serum levels of calcium among different genotypes of IL-6. However, there was a significant variegation $(p<0.05)$ in corrected serum levels of calcium at baseline only in which $\mathrm{CC}$ genotype patients expressed higher levels than GG and GC genotypes once. According to individual IL-6 genotypes, patients with GG genotype displayed meaningful $(p<0.05)$ change in corrected serum calcium levels with lapse of time, followed by GC genotype, while $\mathrm{CC}$ genotype were insignificantly changed. 
Table 5. Corrected serum calcium levels (mg/dl) in study groups throughout the study.

\begin{tabular}{|c|c|c|c|c|c|}
\hline \multirow[t]{2}{*}{ Variables } & \multicolumn{2}{|c|}{ Patients } & \multicolumn{2}{|c|}{ Control } & \multirow[t]{2}{*}{$P$ value $^{a}$} \\
\hline & Mean & $S D$ & Mean & $S D$ & \\
\hline Baseline & 8.27 & 1.59 & 8.91 & 0.87 & 0.003 \\
\hline 3 months & 7.7 & 1.14 & --* & -- & -- \\
\hline 6 months & 8.54 & 0.58 & -_* & -- & -- \\
\hline $\mathrm{P}$ value $^{b}$ & $<0$. & & -- & -- & -- \\
\hline \multicolumn{6}{|c|}{$\begin{array}{l}a \text { :Independent } 2 \text { sample t-test } \\
b: \text { One-way ANOVA (parametric test); p-value between } \\
\text { baseline and } 3 \text { months }=0.058 \text {, between } 3 \text { months and } 6 \\
\text { months }<0.001 \\
*: \text { Values were not measured because these subjects presented } \\
\text { without any disease or condition that may have a significant } \\
\text { effect on serum calcium levels }\end{array}$} \\
\hline
\end{tabular}

Table 6. Corrected serum calcium (mg/dl) divided by IL-6 gene polymorphism. Data expressed as mean \pm SD.

\begin{tabular}{|c|c|c|c|c|}
\hline Variables & GG & GC & $\mathrm{CC}$ & $P$ value \\
\hline $\begin{array}{l}\text { Control } \\
\text { baseline }\end{array}$ & $8.8 \pm 0.9$ & $9.1 \pm 0.7$ & -- & $0.726^{a}$ \\
\hline $\begin{array}{l}\text { Patient } \\
\text { baseline }\end{array}$ & $8.1 \pm 1.6$ & $8.1 \pm 1.1$ & $10.1 \pm 2.5$ & $0.028^{b}$ \\
\hline $\begin{array}{l}\text { Patient } 3 \\
\text { months }\end{array}$ & $7.7 \pm 1.2$ & $7.5 \pm 1.0$ & $8.0 \pm 0.9$ & $0.657^{b}$ \\
\hline $\begin{array}{c}\text { Patient } 6 \\
\text { months }\end{array}$ & $8.6 \pm 0.6$ & $8.6 \pm 0.6$ & $8.1 \pm 0.9$ & $0.200^{b}$ \\
\hline $\mathrm{P}$ value & $<0.001^{c}$ & $0.003^{c}$ & $0.247^{c}$ & \\
\hline \multicolumn{5}{|c|}{$\begin{array}{l}{ }^{a}: \text { Independent } 2 \text { sample t-test } \\
{ }^{b}: \text { One-way ANOVA } \\
{ }^{c}: \text { Trend ANOVA (among patients group only) }\end{array}$} \\
\hline
\end{tabular}

Present study observed a statistically nonsignificant increase in serum level of $1,25(\mathrm{OH})_{2}$ vitamin $\mathrm{D}_{3}$ in $\mathrm{CKD}$ patients when compared to normal healthy subjects at baseline; moreover, the current study showed that serum levels of $1,25(\mathrm{OH})_{2}$ vitamin $\mathrm{D}_{3}$ were significantly increased $(\mathrm{p}<0.001)$ in CKD patients throughout the study as shown in Table 7. As illustrated in Table 8, the control group had a significant difference in serum levels of $1,25(\mathrm{OH})_{2}$ vitamin $\mathrm{D}_{3}$ between $\mathrm{IL}-6$ genotypes $(\mathrm{p}<0.05)$, while in patients group all different IL-6 genotypes had no significant differences in serum levels of $1,25(\mathrm{OH})_{2}$ vitamin $\mathrm{D}_{3}$ at all time periods. According to individual genotypes of IL-6, patients having G G genotype showed more significant increase in serum level of $1,25(\mathrm{OH})_{2}$ vitamin $\mathrm{D}_{3}$ with time, followed by CC genotype, while GC genotype exhibited a nonsignificant $(p>0.05)$ elevation $\mathrm{i} n$ serum level of $1,25(\mathrm{OH})_{2}$ vitamin $\mathrm{D}_{3}$ over time.

Table 7. Serum level of $1,25(\mathrm{OH})_{2}$ vitamin $\mathrm{D}_{3}$ (pmol/l) in study groups throughout the study.

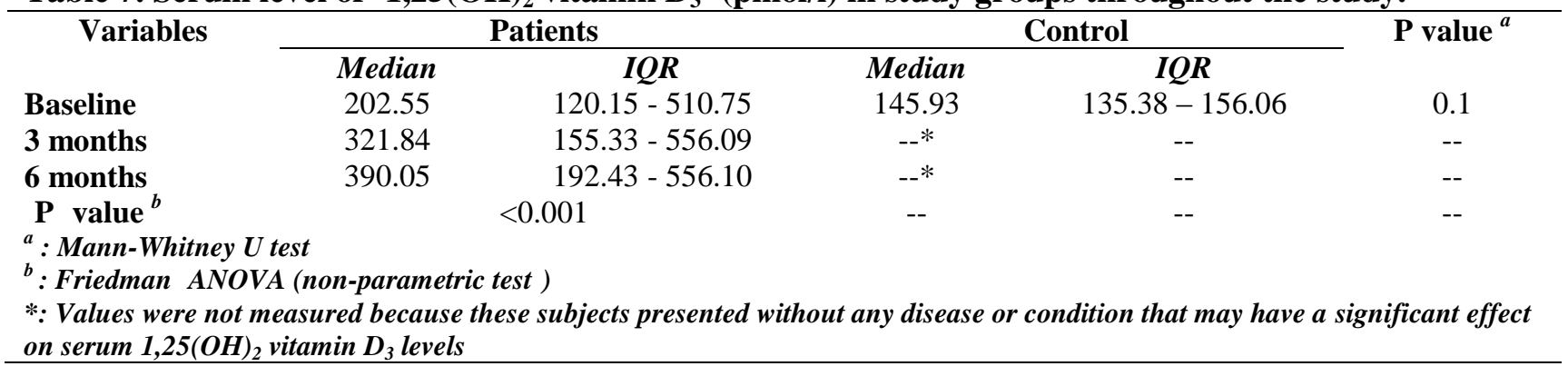

Table 8. Serum $1,25(\mathrm{OH})_{2}$ vit $\min \mathrm{D}_{3}$ levels (pmol/l) divided by IL-6 gene polymorphism. Data expressed as median (IQR).

\begin{tabular}{|c|c|c|c|c|}
\hline Variables & GG & GC & $\mathbf{C C}$ & $P$ value \\
\hline Control baseline & $\begin{array}{c}139.4 \\
(134.6-150.2)\end{array}$ & $\begin{array}{c}156.4 \\
(149.3-227.4)\end{array}$ & -- & $0.032^{a}$ \\
\hline Patient baseline & $\begin{array}{c}194.3 \\
(118.2-486.1)\end{array}$ & $\begin{array}{c}384.1 \\
(126.5-556.1)\end{array}$ & $\begin{array}{c}128.3 \\
(94.4-205.2)\end{array}$ & $0.134^{b}$ \\
\hline Patient 3 months & $\begin{array}{c}340.3 \\
(151-556.1)\end{array}$ & $\begin{array}{c}391.3 \\
(198.8-556.1)\end{array}$ & $\begin{array}{c}179.4 \\
(149.5-269.8)\end{array}$ & $0.257^{b}$ \\
\hline Patient 6 months & $\begin{array}{c}408.6 \\
(190.7-556.1)\end{array}$ & $\begin{array}{c}379.9 \\
(211.6-556.1)\end{array}$ & $\begin{array}{c}365.3 \\
(163.6-500.2)\end{array}$ & $0.807^{b}$ \\
\hline $\begin{array}{c}\text { P value } \\
{ }^{a}: \text { Mann-Whitney U test } \\
{ }^{b}: \text { Kruskal-Wallis test } \\
{ }^{c}: \text { Friedman ANOVA (amo }\end{array}$ & group only) & $0.181^{c}$ & $0.041^{c}$ & \\
\hline
\end{tabular}


As illustrated in Table 9, the median value of serum PTH for patients at baseline was significantly $(p<0.05)$ higher than control, on the other hand, median values of serum PTH in patients had been significantly increased from baseline toward 6 months. As illustrated in Table 10, the control group had an insignificant ( $>>0.05)$ difference in serum PTH levels between IL-6 genotypes at all time periods. Similar observations were recorded for patients group with different IL-6 genotypes. According to individual genotypes of IL-6, patients having GG gen o type showed a more sig ificant raise in serum levels of PTH, foll wed by $\mathrm{CC}$ genotype, while C G genotype were insignificantly elevated by time.

Table 9. Serum PTH levels (pg/ml) in the study groups throughout the study.

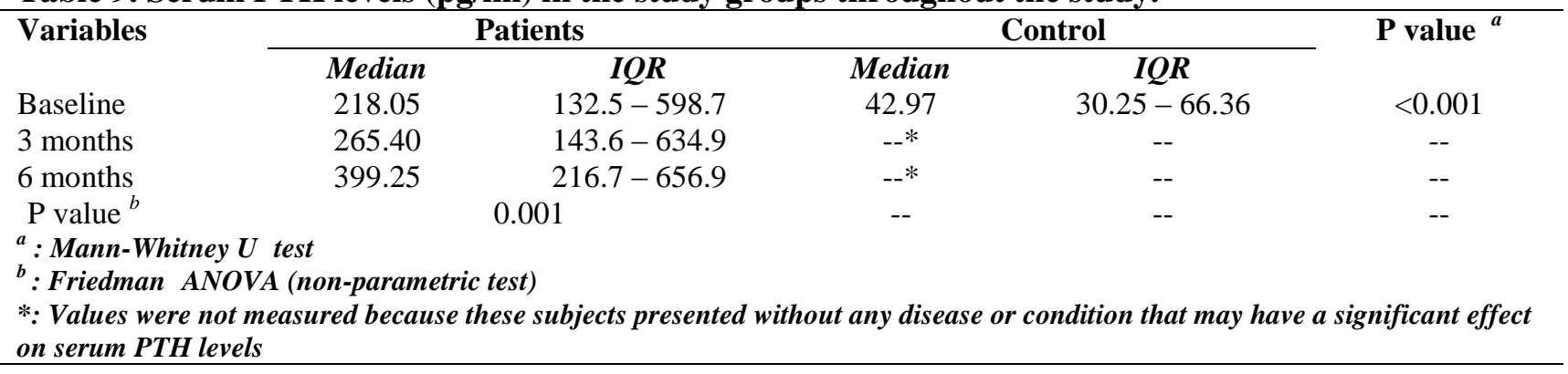

Table 10. Serum PTH levels (pg/ml) divided by IL-6 gene polymorphism. Data expressed as median (IQR).

\begin{tabular}{|c|c|c|c|c|}
\hline $\begin{array}{l}\text { Variables } \\
\end{array}$ & GG & GC & $\mathrm{CC}$ & P value \\
\hline Control baseline & $\begin{array}{c}44.7 \\
(30.3-73.2)\end{array}$ & $\begin{array}{c}31.3 \\
(28.6-58.8)\end{array}$ & -- & $0.266^{a}$ \\
\hline Patient baseline & $\begin{array}{c}218.1 \\
(130.2-599.1)\end{array}$ & $\begin{array}{c}262.9 \\
(176.4-880.7)\end{array}$ & $\begin{array}{c}168.7 \\
(109.0-203.7)\end{array}$ & $0.199^{b}$ \\
\hline Patient 3 months & $\begin{array}{c}249.8 \\
(130.0-585.4)\end{array}$ & $\begin{array}{c}271.6 \\
(161.1-906.6)\end{array}$ & $\begin{array}{c}357.2 \\
(180.7-686.8)\end{array}$ & $0.721^{b}$ \\
\hline Patient 6 months & $\begin{array}{c}385.0 \\
(193.9-649.5)\end{array}$ & $\begin{array}{c}446.2 \\
(225.6-662.1)\end{array}$ & $\begin{array}{c}399.3 \\
(236.7-785.0)\end{array}$ & $0.859^{b}$ \\
\hline $\begin{array}{c}\text { P value } \\
{ }^{a}: \text { Mann-Whitney U test } \\
{ }^{b}: \text { Kruskal-Wallis test } \\
{ }^{c}: \text { Friedman ANOVA }(a\end{array}$ & ents group only & $0.471^{c}$ & $0.041^{c}$ & \\
\hline
\end{tabular}

\section{Discussion:}

The current study was made in an attempt to offer some evidence regarding the association between genetic polymorphism of IL-6 gene and CKD-MBD in Iraqi population in view of the high prevalence of CKD. The present study showed a statistically significant increase in serum phosphorus levels in CKD patients as compared to normal healthy subjects at baseline. In addition, the current study showed that serum levels of phosphorus were not significantly changed in CKD patients throughout the study. Hyper phosphatemia is the most prevalent mineral abnormalities among patients with ESRD (15). In this context, Freethi et al. (15) reported a statistically significant elevation in serum phosphorus levels in CKD cases when compared to controls. Gallieni et al. (16) had also found a significant elevation $(\mathrm{p}<0.001)$ in phosphorus levels in the serum of CKD patients at stage 5 throughout 6 months follow-up study. Moreover, Floege et al. (17) observed a significant elevation in serum phosphorus levels and concluded that high phosphorus levels can be considered as a significant risk factor for mortality in CKD patients. While in Spoto et al. (11) study, an insignificant difference in serum phosphorus levels was observed in 52 CKD patients with CC genotype when compared with 703 CKD patients with GC/GG genotype.

The present study observed a statistically significant reduction in corrected serum calcium levels in CKD patients as compared to normal healthy subjects at baseline. Moreover, the current study showed that corrected serum levels of calcium were significantly changed in CKD patients throughout the study. It had been found that hypocalcemia is quite uncommon in CKD patients at stage 3 and early stage 4 , but more often observed during stage 5 (18). Besides that, hyperphosphatemia that has occurred as a result of impaired renal function in CKD patients is the main stimulus for the reduction in calcitriol production 
that leads to a reduction in calcium absorption from the gut; therefore, hypocalcemia and hyperparathyroidism ensued (19). Freethi et al. (15) reported a statistically significant low serum levels of calcium in CKD subjects when compared to controls . While Gallieni et al. (16) had found a significant reduction $(\mathrm{p}<0.001)$ in serum calcium levels in stage 5 CKD patients at the end of their study when compared with their baseline values. On the other hand, Lim et al. (20) showed that low serum calcium is associated with increased risk of needing renal replacement therapy and rapid renal function progression in CKD patients at stage 3-4. No other studies that evaluated the effect of genetic polymorphism of IL-6 gene on corrected serum calcium in CKD patients were found.

Observations recently have shown that kidney disease can be associated with higher incidence rate of vitamin D deficiency or insufficiency, and severely proteinuric patients have the lowest values (21). However, the present study observed a statistically non-significant increase in serum $1,25(\mathrm{OH})_{2}$ vitamin $\mathrm{D}$ levels in CKD patients as compared to normal healthy subjects at baseline; moreover, the current study showed that serum levels of $1,25(\mathrm{OH})_{2}$ vitamin $\mathrm{D}$ were significantly increased $(p<0.001)$ in CKD patients throughout the study. A possible explanation for this elevation is that the majority of these patients were receiving vitamin D supplementation (alfacalcidol) throughout this study. Optimal vitamin D status is an important factor to reduce PTH secretion in CKD patients. Circulating $25(\mathrm{OH})$ vitamin D provides a substrate for renal 1- $\alpha$-hydroxylase $(C Y P 27 B 1)$ that converts $25(\mathrm{OH})$ vitamin $\mathrm{D}$ to its more active form; $1,25(\mathrm{OH})_{2}$ vitamin $\mathrm{D}_{3}$, which binds to receptors of vit min D in the parathyroid cell to reduce PTH secretion (21). Despite that patients with CKD have reduced enzyme activity of $1-\alpha$-hydroxylase in the kidneys (22), the parathyroid gland itself also contains $1-\alpha$-hydroxylase so that the metabolically vitamin $\mathrm{D}$ active form can locally be produced in a paracrine/autocrine fashion to inhibit PTH secretion. Several other tissues such as breast, placenta, colon, and prostate also contain 1- $\alpha$ hydroxylase, which further supports the role for the regulation of paracrine/autocrine by $1,25(\mathrm{OH})_{2}$ vit $\min \mathrm{D}_{3}(20)$. It is interesting to note that in CKD patients with secondary hyperparathyroidism and low se um $25(\mathrm{OH})$ vitamin $\mathrm{D}$, there is a positive relationship between level of $25(\mathrm{OH})$ vitamin D and levels of $1,25(\mathrm{OH})_{2}$ vit min $\mathrm{D}_{3}$, in contrast to what is found in healthy subjects. Therefore, when the level of $25(\mathrm{OH})$ vitamin $\mathrm{D}$ are elevated by vitamin $\mathrm{D}$ therapy, one might anticipate an elevation in the levels of $1,25(\mathrm{OH})_{2}$ vitamin $\mathrm{D}_{3}$
(19). Chandra et al. (21) reported that raising se um $25(\mathrm{OH})$ vitamin D levels more than two-fold with cholecalciferol therapy in CKD patients was associated with increases in $1,25(\mathrm{OH})_{2}$ vi amin $\mathrm{D}_{3}$ with a trend towards significance $(\mathrm{P}=0.07$ after 12 weeks of treatment). In addition to that, Jean et al. (23) reported that the administration of a monthly 100,000 IU dose of cholecalciferol during a 15-month period appeared to be an effective strategy in correcting vitamin D insufficiency in approxi ately $90 \%$ of CKD patients on hemo dialysis. This strategy was presented without any evident mi eral metabolism toxi ity with the most significant con equences were an elevation in serum levels of $1,25(\mathrm{OH})_{2}$ vita in $\mathrm{D}_{3}$ and a reduction in PTH serum levels and bone markers (23). Marckmann et al. (24) reported that cholecalciferol supplementation in CKD patients caused a significant elevation in $1,25(\mathrm{OH})_{2}$ vitamin $\mathrm{D}_{3}$. This increment was statistically significant in nonhemodialysis patients, while in patients on hemodialysis, the increase was smaller and nonsignificant. These findings indicate that circulating concentrations of $25(\mathrm{OH})$ vit min $\mathrm{D}$ are necessary for the production of $1,25(\mathrm{OH})_{2}$ vitamin $\mathrm{D}_{3}$ in $\mathrm{CKD}$ patients who have limited renal 1 - $\alpha$-hydroxylase activity (24). No other studies that evaluated the effect of genetic polymorphism of IL6 gene on serum $1,25(\mathrm{OH})_{2}$ vitamin $\mathrm{D}_{3}$ in CKD patients were found.

The present study observed a statistically significant elevation in serum PTH levels in CKD patients as compared to normal healthy subjects at baseline. In addition to that, the current study showed that serum levels of PTH were also significantly increased in CKD patients throughout the study. During early stages of CKD, intact PTH levels are typically elevated and this elevation might be contributed to various complications including bone disease, uremic pruritus, cognitive and sexual dysfunction, and higher cardiovascular morbidity and mortality (25), as well as, secondary hyperparathyroidism is an insidious disease that is developed early in the course of CKD and increased in severity as the GFR deteriorates (26). The main cause of secondary hyperparathyroidism in CKD patients is the stimulation of the parathyroid gland in response to decreased circulating calcium and $25(\mathrm{OH})$ vitamin $\mathrm{D}(21)$. It had been reported that calcium exerts negative feedback on the secretion of PTH through the calcium-sensing receptors on the parathyroid gland. The reduction in serum calcium during course of CKD that is caused by phosphate retention with reduced $1,25(\mathrm{OH})_{2}$ vitamin $\mathrm{D}_{3}$ attenuates this feedback and results in 
an elevation in levels of PTH mRNA and parathyroid cells proliferation. The calcium-sensing receptors numbers may also reduce in hypertrophied parathyroid tissue which leads to incomplete suppression of PTH secretion even in the setting of normal or high calcium levels (15). In this context, Goel et al. (27) reported that the level of intact PTH in $174 \mathrm{CKD}$ patients on hemodialysis was $440.9 \pm 397.8 \mathrm{pg} / \mathrm{ml}$. Adhikary et al. (28) also reported that intact PTH level in $80 \mathrm{CKD}$ participants having an indication of hemodialysis was $458.12 \pm 101.27 \mathrm{pg} / \mathrm{ml}$. In addition, Gallieni et al. (16) found a significant elevation $(\mathrm{p}<0.001)$ in serum PTH levels in stage 5 CKD patients at the end of their study when compared with baseline values. While Kim et al. (29) reported that high serum level of intact PTH $(496.0 \pm 189.0 \mathrm{pg} / \mathrm{ml})$ had been found in $10 \mathrm{CKD}$ patients receiving alfacalcidol therapy. No other studies that evaluated the effect of IL-6 gene polymorphism on serum PTH in CKD patients were found.

This study has several clinical implications and the most important one is the effect of IL- 6 gene polymorphisms on the management of CKD-related complications including CKD-MBD.

\section{Conclusions:}

Genetic polymorphism of IL-6 gene at promotor region of $-174 \mathrm{G} / \mathrm{C}$ showed a significant effect on corrected serum levels of calcium on patients with GG genotype followed by GC genotype, while CC were insignificantly affected. It also had a significant effect on serum $1,25(\mathrm{OH})_{2}$ vitamin $\mathrm{D}$ and serum PTH levels on patients with GG genotype followed by CC genotype, while GC genotypes had insignificant effect. On the other hand, genetic polymorphism of IL-6 gene did not show a significant effect on serum levels of phosphate.

\section{Author's declaration:}

- Conflicts of Interest: None.

- I hereby confirm that all the Figures and Tables in the manuscript are mine. Besides, the Figures and images, which are not mine, have been given the permission for re-publication attached with the manuscript.

- The author has signed an animal welfare statement.

- Ethical Clearance: The project was approved by the local ethical committee in University of Tikrit.

\section{References:}

1. Elshamaa MF, Sabry SM, Bazaraa HM, Koura HM, Elghoroury EA, Kantoush NA, et al. Genetic polymorphism of ACE and the angiotensin II type1 receptor genes in children with chronic kidney disease. J. Inflamm. (Lond). 2011; 8: 20.

2. Nigwekar SU, Tamez H, Thadhani RI. Vitamin D and chronic kidney disease-mineral bone disease (CKDMBD). BoneKEy Reports. 2014; 3:498.

3. Bover J, Cozzolino M. Mineral and bone disorders in chronic kidney disease and end-stage renal disease patients: new insights into vitamin D receptor activation. Kidney inter. 2011; Suppl. 1: 122-129.

4. Moe SM, Radcliffe JS, White KE, Gattone VH, Seifert MF, Chen X, et al. The pathophysiology of early-stage chronic kidney disease-mineral bone disorder (CKD-MBD) and response to phosphate binders in the rat. $\mathrm{J}$ Bone Miner Res. 2011; 26(11):2672-81.

5. Kidney Disease: Improving Global Outcomes (KDIGO) CKD-MBD Work Group. KDIGO clinical practice guideline for the diagnosis, evaluation, prevention, and treatment of Chronic Kidney Disease-Mineral and Bone Disorder (CKD-MBD). Kidney Int. 2009; 76 (Suppl 113): S3-S8.

6. Ertuk $\mathrm{S}$ Gene polymorphism association studies in dialysis: bone and mineral metabolism. Semin Dial 2006;19:232-7.

7. Fajar J K, Azharuddin A. The association between interleukin 6-174 $\mathrm{G} / \mathrm{C}$ gene polymorphism and the risk of osteoporosis: A meta-analysis. Journal of Taibah University Medical Sciences. 2017;12(3), 212-220. doi:10.1016/j.jtumed.2016.07.010

8. Blanchard F, Duplomb L, Baud'huin M, Brounais B. The dual role of IL-6-type cytokines on bone remodeling and bone tumors. Cytokine Growth Factor Rev. 2009; 20(1):19-28.

9. Jones SA, Fraser DJ, Fielding CA, Jones GW. Interleukin-6 in renal disease and therapy. Nephrol Dial Transplant, 2015;30(4):564-74. doi: 10.1093/ndt/gfu233

10. Stenvinkel P, Ketteler M, Johnson RJ, Lindholm B, Pecoits-Filho R, Riella M, et al. IL-10, IL-6, and TNF-alpha: central factors in the altered cytokine network of uremia--the good, the bad, and the ugly. Kidney Int. 2005;67(4):1216-33.

11. Spoto B. Mattace-Raso F. Sijbrands E. Leonardis D. Testa A. Pisano A. et al. Association of IL-6 and a functional polymorphism in the IL-6 gene with cardiovascular events in patients with CKD. Clin J Am Soc Nephrol. 2015;10(2):232-240. doi:10.2215/CJN.07000714

12. Gohda T, Shike T, Funabiki K, Shirato I, Tomino Y. An (CA)n dinucleotide repeat polymorphism of the interleukin-6 (IL-6) gene is associated with metacarpal bone mineral density in hemodialysis patients. Clin Nephrol. 2002;57:365-370.

13. Hwang E, Choi BS, Oh K-H, Kwon YJ, and Kim GH. Management of chronic kidney disease-mineral and bone disorder: Korean working group recommendations. Kidney Res Clin Pract. 2015; 34(1):4-12.

14. Al-Radeef MY, Allawi AA, and Fawzi HA. Interleukin-6 gene polymorphisms and serum erythropoietin and hemoglobin in hemodialysis Iraqi 
patients. Saudi J Kidney Dis Transpl. 2018; 29:10429

15. Freethi R, Velayutha Raj A, Ponniraivan K, Rasheed K M, Sundhararajan A, Venkatesan. Study of serum levels of calcium, phosphorus and alkaline phosphatase in chronic kidney disease". Int. J. Med. Res. Health Sci. 2016; 5(3): 49-56.

16. Gallieni M, De Luca N, Santoro D, Meneghel G, Formica M, Grandaliano G, et al. Management of CKD-MBD in non-dialysis patients under regular nephrology care: a prospective multicenter study. J. Nephrol. 2016; 29: 71-78.

17. Floege J, Kim J, Ireland E, Chazot C, Drueke T, de Francisco A, et al; ARO Investigators. Serum iPTH, calcium and phosphate, and the risk of mortality in a European haemodialysis population. Nephrol. Dial. Transplant. 2011; 26(6): 1948-1955.

18. Langman CB , Cannata-Andía JB. Calcium in chronic kidney disease: Myths and realities. Clin. J. Am. Soc. Nephrol. 2010; Suppl 1: S1-S2.

19. Al-Badr W , Martin KJ. Vitamin D and kidney disease. Clin. J. Am. Soc. Nephrol. 2008; 3: 15551560.

20. Lim L-M, Kuo H-T, Kuo M-C, Chiu Y-W, Lee J-J, Hwang S-J, et al. Low serum calcium is associated with poor renal outcomes in chronic kidney disease stages 3-4 patients. BMC Nephrology. 2014; 15:183.

21. Chandra P, Binongo JNG, Ziegler TR, Schlanger LE, Wang W, Someren JT, et al. Cholecalciferol (vitamin $\mathrm{D}_{3}$ ) therapy and vitamin D insufficiency in patients with chronic kidney disease: A randomized controlled pilot study. Endocr. Pract. 2008; 14(1): 10-17.

22. Bajait C, Dakhale G, Pimpalkhute S, Tathod Y, Raghute L. Vitamin D status in chronic kidney disease: An observational study. World J. Pharm. Pharm. Sci. 2016; 5(1): 1376-1382.
23. Jean G, Souberbielle J-C, Chazot C. Monthly cholecalciferol administration in haemodialysis patients: a simple and efficient strategy for vitamin D supplementation. Nephrol. Dial. Transplant. 2009; 24: 3799-3805.

24. Marckmann P, Agerskov H, Thineshkumar S, Bladbjerg E-M, Sidelmann JJ, Jespersen J, et al. Randomized controlled trial of cholecalciferol supplementation in chronic kidney disease patients with hypovitaminosis D. Nephrol. Dial. Transplant. 2012; 27: 3523-3531.

25. Kovesdy CP, Ahmadzadeh S, Anderson JE, KalantarZadeh K. Secondary hyperparathyroidism is associated with higher mortality in men with moderate to severe chronic kidney disease. Kidney Int. 2008; 73: 1296-1302.

26. Chowdary RD, Nellutla R, Reddy PK. Relationship between parathyroid hormone and serum creatinine levels in chronic kidney disease patients. J. Med. Sci. Res. 2015; 3(1): 17-21.

27. Goel N, Pokharna H, Abramowitz MK, Gnanasekaran I. Mineral and bone metabolism disorders in minority incident ESRD patients in an inner-city hemodialysis unit. Einstein J. Biol. Med. 2015; 30: 16-21.

28. Adhikary LP, Pokhrel A, Yadava SK, Khadka D, Thakur R. Relation between serum intact parathyroid hormone level and hematocrit in chronic kidney disease patients. Kathmandu. Univ. Med. J. 2015; 51(3): 220-223.

29. Kim G-H, Choi BS, Cha DR, Chee DH, Hwang E, Kim HW, et al. Serum calcium and phosphorus levels in patients undergoing maintenance hemodialysis: A multicentre study in Korea. Kidney Res. Clin. Pract. 2014; 33(1): 52-57.
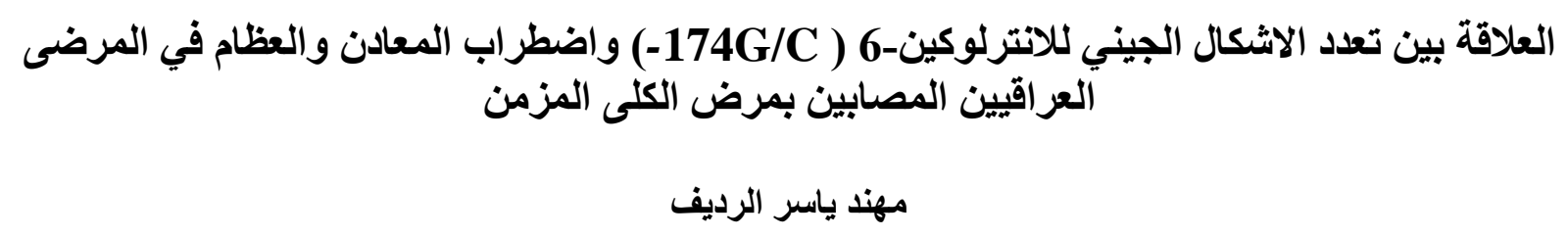

$$
\text { فرع الصيدلة السريرية، كلية الصيدلة، جامعة تكريت، تكريت، العراق }
$$

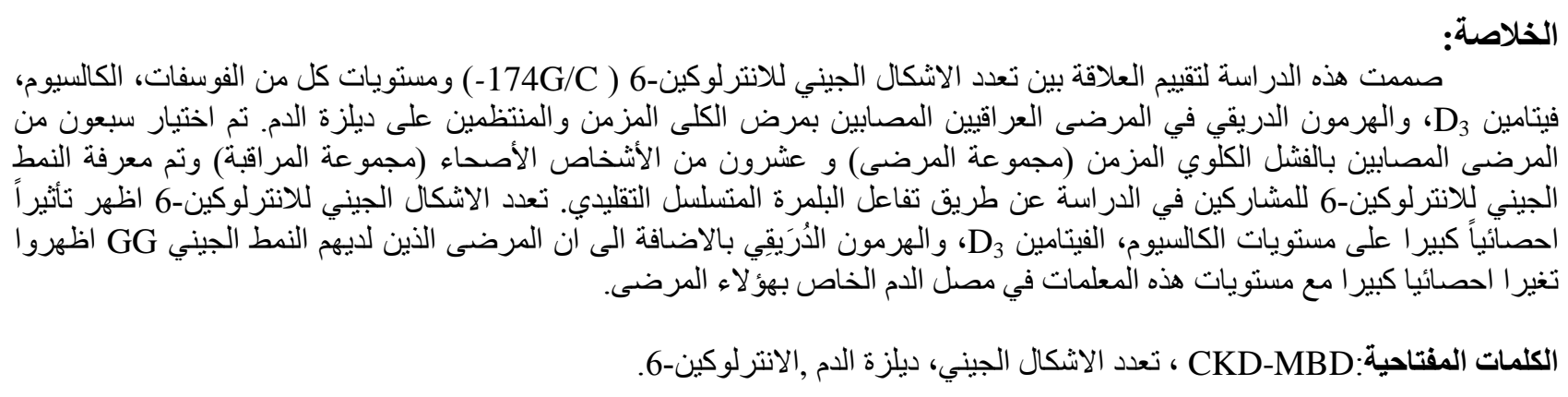

